\title{
Analysis of Factors Contributing to the Success of Project-based Learning College English Teaching
}

\author{
Xiulan Dai \\ College English Teaching Department \\ Langfang Teachers University \\ Langfang, China
}

\begin{abstract}
This paper discusses the factors contributing to the success of PBL College English teaching. Reasonable project design, development of learners' participation awareness and abilities, as well as multi-dimensional project evaluation are all indispensable for the successful implementation of PBL College English teaching. Wellorganized PBL teaching would be effective in cultivating learners' initiative learning awareness and critical thinking ability as well as developing their language proficiency.
\end{abstract}

Keywords—college English teaching; Project-based Learning; evaluation

\section{INTRODUCTION}

Project-based learning (hereafter PBL) teaching which takes action as orientation decomposes the whole learning process into several specific projects or events. A variety of PBL teaching programs which are designed based on action circuits not only teach learners theoretical knowledge and operational skills. More importantly, those teaching programs cultivate their professional ability. The PBL teaching activities make learners not only accept knowledge transferred by the teachers passively, but provide learners with a variety of channels to obtain knowledge and integrate the knowledge learnt in practical use through the construction of open learning atmosphere. Researches have shown that PBL teaching is effective for cultivating learners critical thinking ability and problem-solving ability etc.

These two years, China greatly promote the applicationoriented transformation of local ordinary undergraduate colleges and universities. The core is that the development of those colleges and universities should serve the development of local economy and social development. In order to realize the goal, cultivating application-oriented talents and strengthening learners' employment abilities and entrepreneurial capacities are two main trends. The PBL teaching accords with the demands of the country and the society on application-oriented undergraduate colleges and universities for the cultivation of talents.

\section{TheORIES AND APPLiCATIONS OF PBL TEACHING}

Buck Institute for Education defined teaching method based on PBL as a systematic teaching method which urges learners to acquire knowledge and skills through exploring complex real problems extensively and completing skillfully-designed products and tasks (ET al. Markham 2003). Starting from 1979, the studies of PBL in foreign language teaching abroad has been done for more than 30 years (Zhang Wenzhong, 2012). At present, PBL foreign language teaching has been carried out all over the world and has become an important model. However, with relatively weak theoretical basis, empirical researches based on theories still need to be strengthened.

The studies of PBL foreign language teaching in China started from the end of the 20th century and only has a history of more than 10 years. Many colleges and universities have made a try of the PBL teaching. Suzhou University carried on internet-based PBL teaching in College English writing teaching practices. Research- based College English teaching carried on in Southeast University is also one of the varieties of PBL teaching (Li Xiaoxiang, 2011). Until now, PBL teaching has been applied in EGP (English for general purpose) teaching, ESP (English for specific purpose) teaching, computer-assisted foreign language teaching and community-based language learning, etc.

PBL English teaching is an organically complete process composed of project selection, planning, implementation, result display, reflection and evaluation, etc.. The whole process engages a great amount of cooperation and interaction between the teacher and the students as well as among the students themselves. To summarize, the PBL teaching has the following characteristics. Firstly, PBL teaching attaches great importance to the combination of subject-related core concepts with basic knowledge and skills. Secondly, PBL emphasizes the exploration and solution of real complex questions. Thirdly, PBL focuses on the cultivation of learners' in itiative and innovative thinking ability. In the implementation of project, the functions of English as both a communicative tool and a subject for development of humanism are organically combined.

\section{FACTORS CONTRIBUTING TO THE SUCCESS OF PBL TEACHING}

Although the effectiveness of PBL teaching has been proved, the success of this model is not a natural outcome. To guarantee the success of PBL teaching, the project design, students' participation awareness and abilities, and 
the project evaluation all should be taken into consideration carefully.

\section{A. Project Design}

Reasonable and effective project design is the guarantee of the effects of PBL teaching. Input is the basis of language learning. However, receiving input itself can not guarantee the master of knowledge and skills. Output can arouse learners' attention of problems they have in practical language use so as to trigger the consolidation of input knowledge and acquirement of new knowledge. Therefore, the design of output tasks, the projects in PBL teaching, should be closely related to the contents of the input but have a certain degree of expansion. Only those tasks that satisfy this standard can arouse the students' interests.

Some examples are illustrated here. There is a unit talking about the educational systems in the United States in the textbook the author uses for teaching. Then, ask the students to study the differences between American educational system and Chinese educational system and give a report would be a good project which is meaningful, practical and challenging. By finishing this project, the students can not only practice their languages, but also develop cultural difference awareness. Another topic we have in the textbook is about western traditional festivals. The students can be arranged to introduce more other western festivals besides those introduced in the textbook.

In addition, projects that are related with students' professional knowledge would also be effective to arouse students' interests. When learning tips in a job interview, the teacher can ask the students to design a mock interview. The positions designed should be just what they would actually apply for in future job hunting. Since this project is of practical use, the students finish it with great enthusiasm and careful preparation. Thus, the effects of the project can be guaranteed.

Secondly, the design of the project presentation should be diversified. According to different projects, the presentation can be in different ways. Investigations can be presented with a research report. Stage performance, microvideos or micro-lectures are all good ways to present the results of the projects.

Extracurricular activities can also be used to help the PBL teaching. a variety of English events are organized each semester, such as the speech contest, the writing competition, stage performance competition, etc. To accord with the new trends of English teaching, an English microlesson competition is also organized in the college where the writer works. Students' projects can be displayed in those competitions so as to be known and learnt by more students.

In a word, only reasonable project design can arouse learners' enthusiasm and cab be beneficial for the improvement of language use ability.

\section{B. Learners' Participation Awareness and Ability}

Learners are the main implementers of PBL. Their active participation is not only the guarantee of the success of PBL teaching. More importantly, their active participation is indispensable to their own development. Learners should be fully prepared to undertake a new role in their learning, changing from passive knowledge recipients to become the ones who are responsible for the project and the ones who promote the success of the project.

First of all, from data collection to project presentation, from team building to member communication, all those require learners to devote a great amount of time and energy to the project. Only their learning consciousness and initiative are fully motivated, expected teaching goals and effects can be achieved. To arouse learners' enthusiasm, it is necessary to give the learners who participate in the PBL teaching a training so that they are fully familiar with the role and the responsibility they would have in the PBL. In this process, teachers should continuously strengthen the importance of cooperation, initiative, etc.

\section{1) Cooperation ability}

In PBL teaching, students volunteers to form a project team. Each team should develop a clear project plan and clarify the specific tasks that each member should undertake in the project. When learners do a series of explosive learning centered around a real problem, they have a clear goal of development and strong motivation to cooperate with each other.

Zone of proximal development proposed by Vygotsky pointed out that communication and interaction are important in effective learning. It is also proposed that more capable teachers or peer learners can provide scaffolding in a learner's learning process. Concerning interaction, making full use of the convenience of modern information technology, learners can have a large number of real-time and non-real time communication about the project. In addition to traditional face-to-face and telephone exchanges, learners can establish QQ group, Wechat group etc.. Those new communication tools make interaction more easily.

\section{2) Initiative learning awareness}

As one of the most important ways to self development, the essence of learning is initiative exploration. Only motivated by strong desire for self development, students can become excellent learners through finding, analyzing and solving problems with initiative and persistence.

Since the high integration of language skills in the project, the implementation of the project is a continuous learning process. In the process of materials collection, the learners do a lot of reading; in the process of revising project report or writing self reflection etc., their writing skills are improved. In order to guarantee the effects of project presentation, the students rehearsal several times, which improve their speaking skills. Listening to other teams' presentations train their listening. Language can only be learnt in use. In the initiative implementation of the project, the students put language into practical use and the result is real master of language skills.

In addition, learners should take the initiative to strengthen their information technology ability. The searching tools like Google, Baidu, Yahoo, etc. are 
especially useful to find related materials in the implementation of the project. The learners should develop the ability to make use of the internet, including search information quickly, evaluate the information accurately and process the information efficiently, etc. Besides, the use of digital equipment and a variety of software would be helpful in the project presentation.

\section{3) Critical thinking ability}

The implementation of the project is a complex process that challenges the students' comprehensive ability. In the face of complex problem, the students need to use their critical thinking ability, including identification, classification, comparison, clarification, distinction, interpretation etc. The plans to solve the problem should be considered carefully and reasonably. Various factors affecting the success of the project should all be taken into consideration. The best solution should be picked out by evaluating all possible solutions comprehensively.

\section{Project guidance and evaluation}

Due to dependence on traditional teaching model, some students lack the spirit of team cooperation. To be specific, some students are reluctant to undertake responsibilities in their team, while some others may not be initiative and capable to find and solve problems. Teachers should correct their learning attitude and learning style timely and efficiently and guide the students to develop initiative and cooperative learning awareness. Besides, the teacher should be innovative to organize students' discussions and cooperation so as to promote their initiative learning ability.

The establishment of proper evaluation criteria that accords with the PBL teaching is one of the key problems important for the PBL teaching. Traditional evaluation system attach more importance to the result than the process. One possible problem is that those who have made great progress may not get corresponding reward, a high score, for example. They may be discouraged to do a better project next time.

It is suggested that the evaluation of project should attach importance to the process as well as the results. Teachers' evaluation should cover students' expressive ability, cooperative spirit, degree of initiative and enthusiasm, etc. In addition, students' self-evaluation, team member evaluation and evaluation by other members in a larger group should also be taken into consideration. Providing every learners with opportunities to participate in the evaluation would promote the learners to reflect their learning process.

Evaluation must be organized effectively so as to ensure the integrity and fairness of the evaluation system. Apart from evaluating students' language proficiency, teachers can also evaluate students critical thinking skills reflected in the process of their problem solution. One the one hand, Evaluation can reflect students' learning achievements, on the other hand, evaluation would be an appropriate feedback to students. Multi-dimensional evaluation would give students encouragement and stimulate their further development.

\section{CONCLUSION}

Social need analysis shows that talents who have practical skills and innovative abilities would better satisfy the needs of the society. Action-oriented PBL teaching accords with the goal of talents cultivation set for application-oriented local undergraduates colleges and universities. Introducing PBL teaching model in college English teaching would be a trend. The factors that is indispensable for the success of PBL College English teaching are discussed in this paper. The project design, students' participation awareness and abilities, and the project evaluation all should be taken into consideration carefully.

\section{REFERENCES}

[1] Buck Institute for Education. What Is PBL? http:://www. bie org/about/ What is PBL.2010.

[2] Markham T. Larmer J \& Ravitz J. Project Based Learning Handbook: A Guide to Standards focused Project Based Learning ( 2nd Ed. ) [M] . Novato, California: Buck Institute for Education, 2003.

[3] Li Xiaoxiang. "Cultivation of innovative thinking and English application ability - exploration of research-based college English teaching model in southeast university", Chinese College Teaching, Nov.2011.

[4] Wangwei. "Theoretical exploration and practices of research-based College English learning in application-oriented undergraduates colleges", Journal of Liaoning Institute of Science and Technology, May2014.

[5] Zhang Wenzhong. "Thirty years development of PBL foreign language teaching researches abroad", Chinese Foreign Language, Feb.2012. 